九州大学学術情報リポジトリ

Kyushu University Institutional Repository

\title{
A Study on the Development of Tenancy in the United States prior to 1935
}

Tei, Shika

Cho, Kenji

Seminar of Farm Management, Faculty of Agriculture, Kyushu University

https://doi.org/10.5109/23826

出版情報：九州大学大学院農学研究院紀要. 30 (4)，pp.225-245，1986-09. Kyushu University バージョン：

権利関係 : 
J. Fac. Agr., Kyushu Univ., 30 (4), 225-245 (1986)

\title{
A Study on the Development of Tenancy in the United States prior to $\mathbf{1 9 3 5}$
}

\author{
Shika Tei (Shy-hwa Cheng)* and Kenji Cho \\ Seminar of Farm Management, Faculty of Agriculture, \\ Kyushu University 46-07, Fukuoka 812 \\ (Received January 13, 1986)
}

\begin{abstract}
This is a critical review of the development of tenancy in the United States before 1935. The rate of tenancy had gradually increased since 1860's and reached to over forty percent of the total farms in the United States in 1935. Writers aim in this study to identify the economical and noneconomical causes and problems of the development of tenancy in the United States. It is primarily for the purpose to get some useful suggestions and implications for Japan, Taiwan or other countries where the development of tenancy is now needed as a basic means of the structural improvement of agriculture,
\end{abstract}

\section{INTRODUCTION}

The enlargement of farm scale is one of the most significant subject in improving the efficiency of agriculture especially in Japan, Taiwan, Korea and some other Asian countries where the system of small-sized farms has been inherited to the present day and the national economy itself has reached to industrialized stage. There are two important measures for the enlargement of farm scale, that is, renting and buying. However, the latter seems to become more and more difficult under the existing social and economic conditions in such densely populated industrialized Asian countries as stated above. It is partly because the value of farm land commonly exceeds the value which may be rationalized by the profitability of farming, and partly because the mobility of farm land by means of the transfer of ownership is not high enough for the farmers who intend to expand their farm size depending either on their own savings or acquiring credit. So, the latter becomes a proper and important measure in the enlargement of farm scale. Japan is a good example of it. In her principal policies concerning the structural improvement of agriculture, basic policy has been transferred from the protection of owner-operated farming system to the promotion of the development of tenancy since 1970. But, if concerning with the sound developement of tenancy, there are many factors which should be considered.

Family farming has been a prevailing system of agriculture in the U. S. like in Japan, Taiwan, etc. It was the homestead of family farms. But tenant

* Instructor, Research Institute of Agricultural Economics of National Chung Hsing University, Taiwan, R. 0. C. 
system had once developed to a considerable extent in the early period of this century and also once again in the postwar period during 1950-1960 in the U. S. The tenant rate was increased, on the basis of the number of farms, from 25 percent in 1880 to 42 percent in 1935 in all of her states.

It would be very useful for us to study the experience of the development of tenancy in the U. S. before 1935 . That is, to study the cause of the development of tenancy (including the economical causes and non-economical causes), and to identify the problems involved in the development of tenant system (including the duration of lease, the forms of tenancy, landlord-tenant relationship, and improvements of compensation) should be quite suggestive for other countries which are trying to develop tenancy under the prevailing system of owneroperated family farms.

The main purposes of the present paper may be described as follows :

(a) To review the growth of the tenancy in the U. S. before 1935.

(b) To identify the causes of the development of tenancy.

(c) To identify the problems relevant to the development of tenancy, and then to draw some implications from the experience of the case in the U. S.

For the sake of convienience, this study is limited to the consideration of the experience in the U. S. prior to 1935. It was one of the stages when tenancy had remarkably developed with the reformation of social structure as well as with the development of commercial agriculture in the U. S.

The writing is concentrated on the literature about the development of tenancy in the U. S. before 1935 which was provided by H. C. Taylor, L. C. Gray, John D. Black, R. M. Allen, C. L. Holmes, R. T. Ely, B. R. Stauber, W. J. Spillman, E. A. Goldenweiser, M. D. Harris, G. S. Wehrwein, etc.

In this study, the writers also gave their attention to the differences between the South and the North because the causes of the growth and the characteristics of tenancy are quite different in both regions.

\section{The changes of the situation of tenancy in the $U$. S.}

1. The growth of the tenancy

The growth of the tenancy in the U. S. before 1935 can be described by dividing it into three periods as (1) prior to 1880, (2) from 1880 to 1920 , (3) since 1920.

\section{(1) The tenancy prior to 1880}

There was no reliable statistics relating to tenancy and ownership in this period, but many books and survey reports told us that various types of tenancy such as the cash, the share or fixed quantity of crop lease, and the yearly or a terms of years lease could be seen in the U. S. at that time.

The American farmer of the last quarter of the eighteenth century was as a ruling owner of the land he tilled. There were many reasons for the prevalence of landowning farmers and the scarcity of tenant farmers, (a) the sytem of inheritance (gavelkind custom) helped to maintain the class of landowning farmers, (2) the self-sufficiency character of farm economy at that time made 
it possible for farmers to go into the wildness to carve out a home and to settle upon a new land with little money.

Even in the earlier period of the nineteenth century, in some parts of the North-eastern states, there were some people of the type of English country gentleman-the men who were starving to live after the fashion of the smaller landlords of England who lived in comfort on the rent without putting their own hands to the plow. And the tenants of such type of landlords were as a ruling young men using tenancy as a stepping stone to the position of independent landowning farmers.

In summary, in this period survey reports and other statements gave but slight information as to the quantitative aspect and the method of renting land. Though they gave us no basis of passing judgement on the question as to numerical importance of tenant farmers prior to Civil War, they proved that various types of tenancy were being existed. Tenancy seemed to be increased after the Civil War, and it keeps us from being surprised when we come upon the Census statistics of tenancy in 1880 and find that one-fourth of the farmers were categorized as tenant farmers. However, tenant farmers at that time seemed to be much more numerous in the South due to the dissolution of plantation and reorganization of it to share cropping system.

(2) The tenancy from 1880 to 1920

According to the Census data, the tenant rate was, on the average for the whole country, 25.6 percent in $1880,28.4$ percent in $1890,35.3$ percent in 1900 , 37.0 percent in 1910, and 38.1 percent in 1920 (Table 1), if it is measured by

Table 1. The rate of farms between different tenure classes.

(unit : \%)

\begin{tabular}{|c|c|c|c|c|c|c|}
\hline \multirow[t]{2}{*}{ Clas ses } & \multirow{2}{*}{ Owner } & \multirow{2}{*}{$\begin{array}{l}\text { Part } \\
\text { owner }\end{array}$} & \multirow{2}{*}{ M anager } & \multicolumn{3}{|c|}{ Tenant } \\
\hline & & & & General & Cropper & Total \\
\hline $\begin{array}{r}1880 \\
90 \\
1900 \\
10\end{array}$ & 55. $a$ & $\begin{array}{r}74.4 \\
77.9 \\
9.3\end{array}$ & $\begin{array}{l}1.0 \\
0.9\end{array}$ & $\bar{z}$ & $=$ & $\begin{array}{r}25.6 \\
28.4 \\
35.3\end{array}$ \\
\hline $\begin{array}{l}10 \\
20 \\
25\end{array}$ & $\begin{array}{l}52,752.2 \\
52.0\end{array}$ & $\begin{array}{l}8.7 \\
8.7\end{array}$ & 1: 1 & $\begin{array}{l}29 .-4 \\
28.8\end{array}$ & $\begin{array}{l}8.7 . \\
9.8\end{array}$ & $\begin{array}{l}38,37,01 \\
38.6\end{array}$ \\
\hline $\begin{array}{l}30 \\
35\end{array}$ & 45.3 & 10. 1 & $0: 8$ & 30.6 & 10. 3 & $\begin{array}{l}42.4 \\
42.1\end{array}$ \\
\hline
\end{tabular}

Source : 1954 Census.

the terms of farms; but if it is measured by the terms of acreage of improved land, it changed to 30.2 percent in $1900,32.7$ percent in 1910, and 34.9 percent in 1920. The increase between 1900 and 1920 was greater in terms of farms than in terms of improved land.

Tenant rate increased nearly 13 percent for the past four decades. It was brought about by a significant increase in the South, but it was also attributable to a considerable increase in the North-west and West (Table 2).

The percentage of tenants among farmers by age groups in 1890 and 1920 is shown in Table 3. 
Table 2. The tenant rate of different region in the U. S.

(unit :\%)

\begin{tabular}{rccccr}
\hline Year & Total & North-east & Mid-west & South & west \\
\hline 1880 & 25.6 & 16.0 & 20.5 & 36.2 & 14.0 \\
90 & 28.4 & 18.4 & 23.4 & 38.5 & 12.1 \\
1900 & 35.3 & 20.8 & 27.9 & 47.0 & 16.6 \\
10 & 38.6 & 18.17 .2 & 28.9 & 49.6 & 14.0 \\
25 & 42.4 & 125.0 & 32.0 & 49.6 & 17.7 \\
30 & 13.8 & 34.1 & 55.1 & 18.7 \\
35 & 42.1 & 36.3 & 53.5 & 23.9 \\
\hline
\end{tabular}

Source: 1954 Census of Agriculture, Special Report, Vol. III.

Table 3. Percentage of tenants among farmers in the United States, by age groups, 1890 to 1920 .

(unit: \%)

\begin{tabular}{lcccc}
\hline \multirow{2}{*}{$\begin{array}{c}\text { Age group } \\
\text { (years old) }\end{array}$} & Occupants & of farm & homes & \multicolumn{2}{c}{ Farm } & operators \\
\cline { 2 - 5 } & 1880 & 1890 & 1900 & 1920 \\
\hline Under 25 & 67.4 & 72.2 & 75.6 & 75.8 \\
25 to 34 & 50.2 & 54.7 & 55.0 & 56.5 \\
35 to 44 & 36.0 & 35.6 & 37.3 & 39.7 \\
45 to 54 & 27.7 & 29.3 & 26.8 & 19.2 \\
55 and over & 17.8 & 18.6 & 18.9 & 20.7 \\
55 to 64 & - & 21.0 & 21.1 & 16.5 \\
65 and over & - & 15.1 & 15.1 & \\
\hline
\end{tabular}

Source : Census.

According to Table 3, three-fourths of the farmers under 25 years of age and a slightly over one-half in the age of 25-34 were tenants, while the percentage dropped to approximately 20 percent or less among the farmers in the age of 55 or over.

This fact and another fact which the increase in tenant rate exceeded in terms of farms than in terms of improved land indicate that the growth of tenancy in this period proceeded as a substitution of younger farmers for those in higher age groups who retired from farming without the increase in the average size of farms.

Connecting to the above, it was the phenomena that the number of absentee owners in the U. S. was very small. Retired farmers and landlords who lived in the same county where their estates located constituted 78.8 percent and 15.9 percent lived in another counties within the same state, 5.3 percent outside of the state in the case of the 1934, 346 farms in the U. S. for which the names and post-office addresses of the owners were reported (Taylor, 1925). It was one of the characteristic features of land tenure system in the U. S. in contrast with those in England where large-sized absentee landlords were the most frequent cases. And the fact in the LJ. S. as compared with long term cash renting was common in England and seemed to be closely related with the difference in the type of landlords in both countries.

(3) The tenancy since 1920 
The tenant rate had kept on a slightly increasing trend since 1920 except in the North-east. As a result, it reached to 42.1 percent in 1935 as compared with 25.6 percent in 1880 . The two-thirds of the net increase in the tenant rate between 1880 and 1935 or about 17 percent of the total farms was the growth of tenancy, while the rest was the growth of mortgage indebtedness (Black and Allen, 1937). From 1880 to 1935, the proportion of the farm land rented had increased 2.5 percent per decade, that mortgaged by owner operators was 1.5 percent, and the two combined constituted 4.0 percent per decade. The number of part-owner farms had risen from 8 percent of the total number of farms in 1910 to 10 percent in 1935, and the mortgaged owner-operated and part-owner farms had increased from 20 percent in 1890 to 25 percent in 1930.

The ratio of tenant farms operated by relatives of the landlords occupied 19.2 percent of the total rented farms in 1930, but the ratio averaged 15 percent in the South and 30 percent in the North. In 1930, croppers as tenants was 8.7 percent of all farms, 22.9 percent of all tenants.

If it is observed by region in Table 3, the growth of tenancy in the Mid-west seems to have received enough attention. The remarkable increase in the rate of tenancy in this region since 1880 was often attributed to the high price of the Mid-western land. Rented farms resulted in abundance, and they were large in the size of the farm than owner-operated farms in this fertile region.

2. The geographical distribution of tenancy before 1935

If we concern about the geographical distribution of tenancy in the U. S. before 1935, the following statements written by R. T. Ely and G. S. Wehrwein would be worthwhile to quote :

"...The 100 th Meridian states have more farm land than any other region, but the South exceeds all others in the number of farmers.

The West and East are comparatively unimportant compared to the Mississippi Valley and the South. For this reason the percentage of tenancy means more in intensively utilized agricultural regions. The South has 48 percent of all tenants of the U. S., the 100 th Meridian states 22 percent, and the Corn Belt 16 percent. It is also in these sections that crops are raised which lend themselves to tenant farming. Almost three-fourths of the cotton farms are cultivated by renters and croppers. One-crop specialties in general lend themselves to tenant farming and are admirably suited to the needs of absentee landlords. The share is easily established, the product is readily divided, and the tenant can be supervised without much trouble. The more complex fruit, poultry, dairy farms and stock ranches are largely operated by owners.

...Custom, inheritance, and other institutional factors are sometimes stronger than the economic elements. In the South human and historical factors operate in the direction of high proportion of tenant farms. The South raises rice, tobacco, and cotton, all of them are good tenant crops. It also has the Negro and a special type of White tenant. This combination explains why in some of the Southern states more than two-thirds of the farmers are renters. ..." 
When we compare the South and the North, the followings can be pointed out as the main differences concerning the tenancy.

(1) Percentage of tenant farms was higher in the Southern states than that in the Northern states. This difference was closely associated with the difference in the kind of major crops as well as the types of farming in each region.

(2) The character of landlords and tenants was also much different by region. In the South, the rented farms were smaller because the unit of operation on the cropper and the usual share-rented farms tended to be what one family with one mule could grow and harvest, hiring one man and helping from his family. And more fundamentally, it was due to the South's high ratio of population on the land and its concentration of land ownership in fewer hands. In the North, rented farms tended to average larger than owner farms mainly because the landlord ordinarily had one farm and two families and could not live at the accustomed level on the income from a small farm, or at least the tenant could not do so after paying the usual rent. An owner could not retire from farming and lease his farm unless the rent was large enough to support him.

(3) In the Southern states 56 percent of the tenants had been on their farms for less than 2 years, for 21 Northern states were 39 percent. It means that in the South the length of lease is shorter than which is in the North. So, under these circumstances neither the landlord nor the tenant, especially the latter is sufficiently interested in making necessary improvements on the farms.

In the North, however, North-eastern states and Mid-western states were distinct. In the former states, dairy and general farming were the most common types of farming and the percentage of tenant farms was not only relatively low but also kept a decreasing trend since 1900, while cash grain farms were more numerous and the increase of the percentage of tenant farms was proceeded on continuously since 1880 until reaching 36.3 percent in 1935 in the latter states. It was observed that there was also a distinctive difference in land value in the two sub-regions in the North as shown later in Table 10.

3. The forms of tenancy

Many forms of renting contracts were found in the U. S. before 1935. The main forms of renting are designated and the characteristics of each of them may be defined as follows (Gray, 1924).

a. Competitive cash rent : The landlord usually furnishes only the real estate, paying taxes and the money cost of upkeep, but he does not assume the risk nor the responsibility for management.

b. Standing rent : This is a modified form of cash rent. Instead of agreeing to pay a certain amount of money, tenant agrees to pay a certain quantity (not a share) of the products.

c. Share rent: In the U. S. about two-thirds of all rented farms were rented for a share of some or all kinds of products on the farm. In this form of renting the landlord makes certain contributions to the expenses of production, and because his rent depends in part on how well the farm is managed, he is 
likely to contribute freely to his own time as well as his capital to make the business a success. The fractional share is likely to be rather rigidly fixed by custom and varies only as a result of important changes in the system of farming or in the value of land. On a very rich land the fractional share is sometimes higher than on the poorer soil even in the same community.

d. Stock-share lease : The landlord furnishes half and sometimes all of the livestock, pays half of the expenses of farm operations, excepting the expense for labor and machinery, and get one-half of all receipts including receipts from livestock and livestock products. It is a sort of economic partnership and has an advantage of promoting livestock production. Depends on $\mathrm{H}$. C. Taylor's explanation (Taylor, 1925), the landlord furnishes all of the cows in the stock-share system, and provision must be made for maintaining the herd by replacing the old cows with the young ones produced on the farm. The money received from the sale of cows is divided and the young cow reared by the tenant becomes the property of the landlord.

The stock-share lease is the form of tenancy best suited for livestock farms. It was found in the dairy regions of New York, Ohio, Illinois, Wisconsin, Iowa and Minesota. However, a survey report indicated that the rate of farms adopting this form of renting was not more than 5 percent of the rented farms in Iowa (Holmes, 1923). It was partly because the stock which each party wishes to put into the partnership should be carefully appraised at the beginning of the tenancy and the difference in value must be settled in cash, and partly because this form of renting requires the landlord to furnish a great deal of capital without participating equally in management itself and consequently risk becomes larger for the landlord.

The rate of farms and acreages in each of the different forms of tenancy in the U. S. before 1935 is shown in Table 4 and Table 5. It was one of the characteristic features of tenancy in the U. S. prior to 1935 that cash-rent

\begin{tabular}{|c|c|c|c|c|c|c|}
\hline Year & Cash & $\begin{array}{c}\text { Share } \\
\dot{\bullet} \\
\text { Cash }\end{array}$ & Share & Cropper & Others & $\begin{array}{l}\text { Unable } \\
\text { to be } \\
\text { classified }\end{array}$ \\
\hline 1880 & 31.8 & \multicolumn{2}{|c|}{$68.2(3)$} & \multicolumn{2}{|l|}{-} & - \\
\hline 90 & 35.1 & \multirow{2}{*}{\multicolumn{2}{|c|}{$\begin{array}{l}64.9(3) \\
63.0(4)\end{array}$}} & & & - \\
\hline 1900 & $37.0(1)$ & & & & & - \\
\hline 10 & 30.2 & 5.4 & $59.5(4)$ & - & - & 4.9 \\
\hline 20 & 19. $6(2)$ & 5.2 & 45.6 & 22.9 & $4.2(5)$ & 2.5 \\
\hline 25 & 15.9 & & & & $58.9(6)$ & - \\
\hline 30 & 18.3 & - & & 25.29 .21 & $52.6(6)$ & - \\
\hline 35 & & & & 25.0 & $75.0(7)$ & - \\
\hline
\end{tabular}

(1) : fixed rent lease and unable to be classified are included.

(2) : fixed rent lease is included.

(3) : cropper, others, unable to be classified are included.

(4) : cropper, unable to be classified are included.

(5): the fixed rent lease in the South.

(6) : except of cash cropper is included.

(7) : except of cropper is included.

Source : 1954 Census. 
Table 5. The average rate of different tenancy in the U.S. (unit: \%)

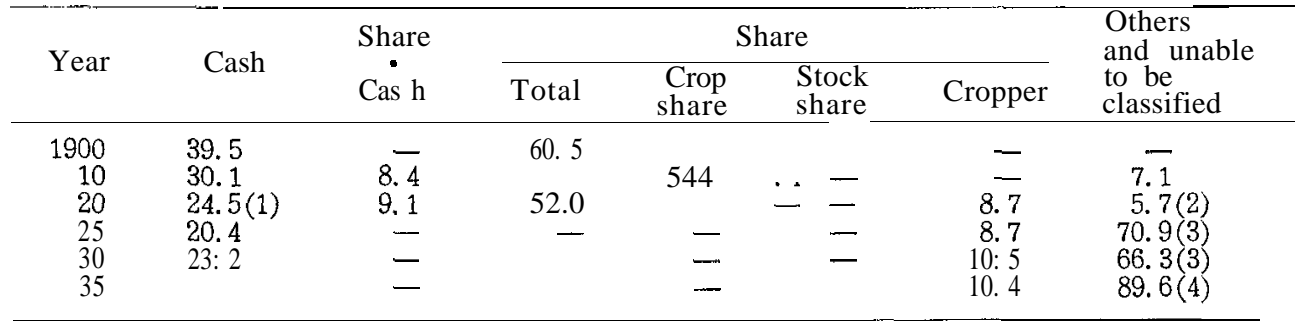

(1) : except of fixed rent lease in the South is included.

(2) : the fixed rent lease in the South.

(3) : except of cash, cropper is included.

(4) : except of cropper is included.

Source : 1954 Census.

system neither constituted but a minor part of the total rented farms nor increased during the decades.

And the followings had been pointed out basing upon actual research on the relation of the types of leasing to farm profits (Holmes, 1923).

(1) Rented farms tended to be the kind with the highest profits under the type of leasing which is most prevalent in the area.

(2) Cash tenants paid a lower rate of rent normally than share tenants did.

The reason why cash tenants received higher profits in normal years for their investment, labor and management was explained by a larger risk that tenants assumed under the cash rent system. The following quotation is an example of the explanation.

"...The main reason is that in renting for cash the farmer assumes all the risk from poor crops and falling prices, if he shifts a part of this risk to the landlord by renting on shares, he must pay the landlord for his risk taking by giving him so large a share that in the average year his return will be smaller than if he had rented for cash. In some areas and under some economic conditions the risk is greater than in others. If tenant alone controlled the method of leasing would be much more cash renting, the landlord desires to rent on shares assuming his part of the risk in order to get the higher return on his investment. ..."

In any case, the fact that crop share system was the type of leasing which most numerous in the number of cases seemed to be closely associated with the fact that landlords in the U. S. especially in the Northern states were usually retired farmers who had enough experiences of farming and resided in the same county where their estates located.

4. The relation of tenancy to types of farming and size of business

(1) Utilization of farm land and source of income

The relation of tenancy to types of farming can be described on the basis of the utilization of farm land and source of income. 
As the stock-share is the type of leasing being adopted on livestock farms, land utilization on share-stock farms tends to be the highest in the percentage of farm area devoted to pasture and hay as compared with other types of tenure, and the lowest among all types of tenure in the percentage devoted to grain. The cropping program on the stock-share farms is designed to support a heavy livestock enterprise and it is particularily the crop-share program is designed to supply a share amount of grain for market.

In contrast with the tenant farms of various types, owner-operated farms tend to specialize in livestock. In other words, owner farms are to be the highest in the percentage in the number of farms in the area specialized in livestock farming. The cash-rent farms show a land utilization more nearly similar to the crop-share farms than to the owner-operated and stock-share ones, while the farms made up of owned and rented land occupy an intermediate position without extreme specialization in either direction.

A long term lease and an active participation of the landlord in the business encourage the livestock enterprise and discourages the more exploitive grain selling system of farming. Short and uncertain tenure of the characteristic of share renting and perhaps the rent is more numerous than cash renting tends to have the opposite effect.

According to a case study in Iowa, the average utilization of farm land of various tenure classes can be shown as Table 6 .

\begin{tabular}{|c|c|c|c|c|c|c|}
\hline Tenure & Pasture & Corn & Oats & $\begin{array}{l}\text { Other } \\
\text { small } \\
\text { grain }\end{array}$ & Hay & Other \\
\hline $\begin{array}{l}\text { Owners } \\
\text { Owners-additional } \\
\text { Caøp-share } \\
\text { Stock-share }\end{array}$ & $\begin{array}{l}32.9 \\
28.26 .05 \\
18.7 \\
38.3\end{array}$ & $\begin{array}{l}29.5 \\
32.33 .58 \\
38.2 \\
27.6\end{array}$ & $\begin{array}{l}14.7 \\
16.6 \\
18: 4 \\
20.5 \\
10.2\end{array}$ & $\begin{array}{l}7.0 \\
8.7 .62 \\
7.3 \\
7.1\end{array}$ & $\begin{array}{r}9.5 \\
8.8 \\
8.1 \\
8.6 \\
10.5\end{array}$ & $\begin{array}{l}6.4 \\
5.7 \\
5.8 \\
6.7 \\
6.3\end{array}$ \\
\hline
\end{tabular}

*As shown by survey reports in six Iowa counties.

Source: Digest from C. L. Holmes, Relation of types of tenancy to types of farming in Iowa, p. 353.

Source of gross receipts provides the best criteria for the type of farming. Based upon the case study in Iowa, the stock-share farms exceeded not only in the absolute amount of the receipts from cattle, but also in the percentage of the total receipts which came from this source, as compared with 40 percent of the receipts derived from the sale of hogs on owner-operated, cash-tenant and stock-share tenant farms. Stock-share rented farms got only 6 percent of gross receipts from the sale of corn and owner-operated only 9.5 percent, while crop-share farms derived more than one-third of their gross income from this source.

Crop-share renting necessarily results in the major portion of the crops leaving the farm as grain rather than being fed. The landlord takes from one-third to one-half of the whole produce as rent. So, the tenant with short tenure and inadequate equipment usually finds it inexpedient to feed all the 
shares of his own.

(2) Size of business

A fairly close relationship was observed between the type of tenure and the size of farm business too, excepting the South where tenants meant the smallsized share-croppers working with poor equipment.

Table 7 was a result of a case study in six Iowa counties in 1914 and 1918.

Table 7. The average size of the farm business of different tenure classes.*

\begin{tabular}{l|cc}
\hline & Area acres & Inv. \$ \\
\hline Owners & 181 & 42,540 \\
Owners-add. & 196 & 45,484 \\
Cash & 201 & 50,913 \\
Crop-share & 183 & 26,858 \\
Stock-share & 227 & 49,102 \\
\hline
\end{tabular}

*The same as Table 6 .

Source: Digest from C. L. Holmes, Relation of types of tenancy to types of farming in Iowa, 1923, p. 348.

It indicated that tenants had a tendency to operate larger farms and employ larger investment than owners. To describe more minutely, the average size of business in both terms of area and investment was the largest on cashtenant and stock-share tenant farms and the smallest on owner-operated farms, though as far as the amount of investment is concerned it was still smaller on crop-share farms than on owner-operated farms.

The reason why tenant farms exceeded owner-operated ones in the size of farm business was attributed to the saving capital. It implies that a man who has a certain amount of fund can operate a larger farm if he acquires land by lease and invests his own capital in stock and equipment instead of investing it in land. On the contrary, tenants are frequently taking less land than they can operate most profitably because they have too small sum to invest. It would be particularily true as for owner farmers in younger generation, and it accounts for smaller size of business on owner farms.

Another fact that crop-share tenant farms were relatively small in the size of business seemed to be attributable to the fact that this type of leasing are most frequently found on farms specialized in cash grain farming with little livestock and tenants who operate such type of farms are most likely younger farmers without enough amount of capital.

Depends on the case study in Iowa, the average receipts from specified sources and average profits to operators can be shown as Table 8 and Table 9.

Cash rented farms, which rank first in profits in the general average. The men who operate their own lands, earn smaller profits than the cash tenants and owner-additional farmers, but larger than the crop-share leases. These difference are to be accounted for largely by the variations in normal size of business under different tenure systems and by the difference in the returns to landlord under the types of renting. 
Table 8. The average receipts from specified sources on farms of various tenures.*

\begin{tabular}{l|ccccc}
\multicolumn{1}{c|}{ Tenure } & Cattle & Hogs & Corn & $\begin{array}{c}\text { Small } \\
\text { grain }\end{array}$ & $\begin{array}{c}\text { Anit }: \% \text { ) } \\
\text { others }\end{array}$ \\
\hline Owners & 19.4 & 40.2 & 9.5 & 12.4 & 18.5 \\
Owners-add. & 18.6 & 35.4 & 13.8 & 14.9 & 17.3 \\
Cash & 15.1 & 40.1 & 14.9 & 15.4 & 14.5 \\
Crop-share & 8.1 & 20.6 & 34.1 & 21.4 & 15.8 \\
Stock-share & 22.0 & 40.0 & 6.0 & 14.0 & 18.0 \\
\hline
\end{tabular}

*The same as Table 6 .

Source: Digest from C. L. Holmes, Relation of types of tenancy to types of farming in Iowa, p. 357.

Table 9. The average profits to operators and rate of returns to landlords under various tenures*.

\begin{tabular}{l|cc} 
& Profits to operators & Returns \% \\
\hline Owners & 1,062 & $-\overline{2}$ \\
Owners-add. & 1,325 & 2.0 \\
Cash & 1,771 & 4.4 \\
Crop-share & 730 & 3.7 \\
Stock-share & 450 & \\
\hline
\end{tabular}

* The same as Table 6.

Source: Digest from C. L. Holmes, "Relation of types of tenancy to types of farming in Iowa", p. 358.

\section{The causes of the development of tenancy}

The causes of the development of tenancy in the U. S. before 1935 may be divided into economical and noneconomical factors and stated as follows.

1. The economical causes of the development of tenancy

\section{(1) High land value}

If the value of land is relatively high comparing with the net returns on land or if the increasing trend in the value of land exceeds that of net earnings on labor and management of farming, the tenancy will be resulted in growth. From the evidence of the relation between land price and tenancy in the U. S. before 1935, we can prove that the higher the land price is, the higher the

Table 10. Ratio of regional average value per acre of farm real estate to average for the United States.*

\begin{tabular}{lrrrrrr}
\hline & 1900 & $\mathbf{1 9 1 0}$ & $\mathbf{1 9 2 0}$ & 1925 & $\mathbf{1 9 3 0}$ & \multicolumn{1}{c}{$\mathbf{1 9 3 5}$} \\
\hline Cotton Belt & 42.3 & 51.5 & 65.9 & 67.1 & 73.4 & 70.2 \\
Corn Belt & 188.9 & 210.1 & 247.3 & 211.9 & 194.4 & 186.4 \\
Wheat Region & 45.6 & 72.5 & 61.2 & 58.2 & 59.7 & 60.8 \\
Dairy Section & 156.9 & 113.4 & 107.4 & 128.0 & 138.4 & 147.9 \\
Average & 110.0 & 112.0 & 119.5 & 114.6 & 111.2 & 108.8 \\
\hline
\end{tabular}

* Based on the reports of census.

Source: B. R. Stauber, Observations on land value trends, Journal of Farm Economics, Vol. XIX, 1937, p. 160. 
tenancy is.

The regional average value per acre of farm real estate in the U. S. during the period from 1900 to 1935 is indicated in Table 10. From this table, we can get an impression that the land value in Cotton Belt and Corn Belt was increased quite remarkably from 1900 to 1920. And since 1920, the average value of land was increased also in Cotton Belt, Wheat Region and Dairy Region. These tendencies seemed to be in accordance with the growth of tenancy in each region.

(2) Low profitableness of investment in land

The value of land which influences the growth of tenancy is the relative value in comparison with the profitableness of farming. In Iowa, the percentage of net returns on investment was not more than 2 or 3 percent in 1913 and 1918. On the contrary, the ordinary interest rate of credit which tenants can borrow to purchase land averaged at least 5 or 6 percent at that time.

Another reason for farmers like to rent a farm than to buy it is that the owner of a mortgaged farm is tied down to his farm and the debt on it. If he desires to change his location or occupation, he must either sell it or find a tenant that is very inconvenient to him.

(3) The rearrangement of plantation system in the South

A large part of the growth of tenancy in the South since Civil War had consisted of the transfer from the laborers to croppers. The Bureau of the Census has insisted upon classifying croppers as tenants, though it is a question whether they may be reasonably considered as independent tenants in a narrow sense or not.

In any case, croppers consisted of 8.7 percent of all farms and 22.9 percent of all tenant farmers in the U. S. in 1920, and it was increased to 12.3 percent and 29.1 percent respectively in 1930. So, if croppers were counted as tenants, the percentage of farms rented would be 55.5 percent in the South and 42.4 percent in the U. S. in 1930.

The plantation system in the South made a concentration of landownership. The land in the South was owned in holdings considerably larger than what would be needed for a family farm. The newly emancipated laborers lacked not only the operating capital but even the means of livelihood while growing crops. Furthermore, they were lacking in experience and unaccustomed to self-direction. There was no banking system to supply farmers and tenants with capital needed. The system of banking especially in the South had largely been developed to serve the financial needs of large plantation rather than small farms. Moreover, the freedom of tenants were restless and unstable as farm laborers.

(4) High wage of labor and the difficulty in obtaining hired laborers

In the U. S. where the scarcity of labor had characterized her social environment, the enormous growth of manufactures and commerce increased the demand of laborers, so that, the wage of labor had greatly risen, and then laborers were not easy to be hired.

If it had been easy to get good hired laborers with low rate of wages, many of the retired farmers would have continued farming with the help of hired 
laborers instead of renting out their land to tenants, and large-size capitalistic farms should have being existed in the U. S. like in England. But it was not the case in the U. S.

\section{(5) The shortage of credits}

According to a research on land-bank 'loans in 1921, not more than 15 percent of the loans made by the Federal Land Bank had been for the purpose of buying farm land, and only one-third of the borrowers were landless. The total loans of the Federal Land Bank represented only about 8 percent of the entire farm-mortgage indebtedness.

It will be clear that the credits afforded by the land-bank system to the landless farmer for the acquisition of land was insufficient at that time. And it may be regarded as one of the factors which related to the development of tenancy in the period prior to 1935 .

In addition to the insufficient supply of farm credits, a relatively low profitability of farming should be referred to also as the factor which made it hard for young man to get loans to acquire land. It was a conclusion of an analysis in 26 farm-management surveys in different parts of the U. S. in 1920 that if a man tried to buy a farm of average value and pay for it together with interest, there would be less than nothing to live on (Gray, 1920).

2. The noneconomical causes of the development of tenancy

(1) The older farmers in retreat

C. J. Galpin and E. F. Moag, the authors of "Farm Tenancy, An Analysis of the Occupancy of 500 Farms" (Galpin and Moag, 1919), gave a good picture of the retreat of farmers in a state in the North-east. The following is a quote from their statements.

“...This constant social phenomenon of retreating old age seems to have a fixed relationship to the advance of youth upon the land and to the combining of the agricultural ladder. When farm land comes under the control of women, instead of leaving the country they tend to stick to the farm in spite of many handicaps, keeping the farmily together, leasing farm to neighbors until the son is old enough to assume the responsibility of management. In 1909 only 8 farmowners began their retreat. They started the retreat by letting their farms to tenants. In 1910, 18 farm-owners were in full retreat by letting their farms to tenants, while 3 farm-owners began their retreat by selling their original farms. ..."

\section{(2) Sentimental considerations}

Sentimental considerations of the farmers would be another factor of the growth of tenancy, that is, it caused retired farmers as well as heirs to keep the ownership of the farm instead of selling it. The farmers have a passion for the ownership of land, a passion which is based not so much on the desire to invest their savings profitably but mainly on the feeling of security and independence, freedom from unemployment, pride of ownership, and frequently the desire to keep the old homestead in the family and to maintain lower standards of living.

This sort of sentimental considerations will cause men to keep the ownership 
of estates, and will likely cause the price of land to be high.

(3) Tenant as a step of agricultural ladder in the $U$. S.

Tenancy is a goal for some farmers. It suggests as a resting place or termination of a carrer. Tenancy is a means of transmission of land property from one generation to another. Tenancy is also a good thing when it represents a rung in the agricultural ladder and means a step upwards in the winning of a competence sometimes and frequently a man begins as an agricultural laborer, saves enough money to become a tenant, then through tenancy acquires enough to purchase a farm, gives back a mortgage and gradually pays for the mortgage.

In the U. S. before 1935, there were many young men climbing the agricultural ladder through the step of tenant. In the paper of "The Agricultural Ladder" (Spillman, 1919) which deals with the rate at which men climb agricultural ladder as shown in the Table 11. There were 52 percent of the farmers through the step of tenant climbing to ownership.

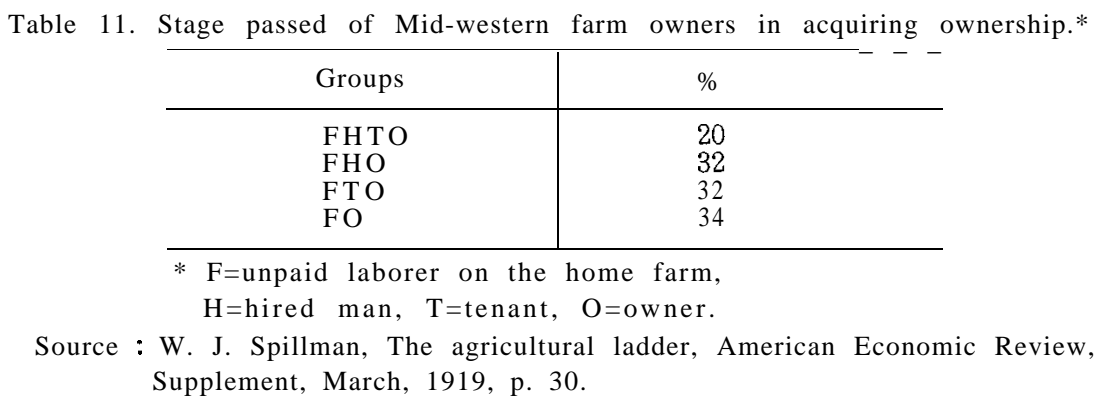

\section{The problems concerning the tenancy in the U.S.}

In practice, if we want to develop the tenancy as an ideal system of land ownership, there are several problems which should be considered, such as the duration of lease, the way of getting a congenial contract, the types of lease and the level of rent, the method of compensations for unexhausted improvements, and so forth. We will refer a little in the present section to some of these problems concerning the tenancy in the U. S. before 1935.

1. The duration of lease

In England, a year to year lease or a term of years lease gave away to long lease along with the development of New Agriculture in the second half of the 18 th century. It was generally recognized in England that the long term lease is a desirable system of leasing particularily for the following reasons.

(1) Long term lease is beneficial to guaranteeing the tenant the continued possession of the farm for a period sufficiently long to encourage investment in improvements.

(2) Long term lease is also beneficial to securing the landlord against improper use of the property during the last few years of the tenancy so that the farm would be returned to the landlord in the productive 
condition.

However, when a decrease or an increase in the circulating value of money occurred for a period of years, or a significant fluctuation happened in the nominal value of agricultural products, the long term lease under the system of cash tenancy would be disadvantageous to proprietors as well as to tenants. Many landlords would not be inclined toward long term leases under such circumstances as the depreciation trend of the circulating value of money or the increasing trend of current price of products. And tenants may not be desirous of long term lease under the reverse circumstances or because they would not likely be desirous of being tied down immediately to particular landlords.

These factors effected to reduce the term of lease even in England. As a matter of fact, the long lease declined during the period following the close of the Continental Wars, mainly because the prices of agricultural products were depressed and the farmer did not find it profitable to farm their rented land so intensively as formerly even if they had long lease.

Contrary to the case in England, the length of leases was very short in the U. S. It was often pointed out that the landowners in the U. S., especially in the Northern states, were so generally consisted of retired farmers that the

Table 12. The length of tenures on tenant farms in the U. S.*

\begin{tabular}{|c|c|c|c|c|c|}
\hline \multirow{3}{*}{$\begin{array}{l}\text { Type of tenure and years on } \\
\text { the farm }\end{array}$} & \multicolumn{5}{|c|}{$\begin{array}{l}\text { Tenants having been on the same farm each specific } \\
\text { number of years (percent). }\end{array}$} \\
\hline & \multirow{2}{*}{$\begin{array}{l}\text { United } \\
\text { States }\end{array}$} & \multirow{2}{*}{$\begin{array}{l}\text { The } \\
\text { North }\end{array}$} & \multirow{2}{*}{$\begin{array}{l}\text { The } \\
\text { West }\end{array}$} & \multicolumn{2}{|c|}{ The South } \\
\hline & & & & White & Colored \\
\hline \multicolumn{6}{|l|}{ All tenants : } \\
\hline $\begin{array}{l}\text { Less than } 1 \text { year } \ldots . \ldots \ldots \ldots \ldots \ldots \ldots . . . \\
1 \text { year but less than } 2 \text { years } \ldots \ldots \\
2 \text { years but less than } 5 \text { years } \ldots \ldots . \\
5 \text { years but less than } 10 \text { years } \ldots \\
10 \text { years and over } \ldots \ldots \ldots \ldots \ldots \ldots \ldots \ldots\end{array}$ & $\begin{array}{r}33.4 \\
17.1 \\
29.6 \\
12.0 \\
7.9\end{array}$ & $\begin{array}{r}27.6 \\
17.8 \\
30.5 \\
14.7 \\
9.4\end{array}$ & $\begin{array}{r}33.0 \\
18.5 \\
31.8 \\
11.0 \\
5.7\end{array}$ & $\begin{array}{r}42.1 \\
18.0 \\
\mathbf{2 6 . 9} \\
\mathbf{8 .} 4 \\
\mathbf{4 . 6}\end{array}$ & $\begin{array}{l}28.8 \\
15.0 \\
32.0 \\
13.7 \\
10.5\end{array}$ \\
\hline \multicolumn{6}{|l|}{ Cash tenants : } \\
\hline $\begin{array}{l}\text { Less than } 1 \text { year } . . . . . . . . . . . . . . . . . . \\
1 \text { year but less than } 2 \text { years } \ldots \ldots . \\
2 \text { years but less than } 5 \text { years } \ldots \ldots . \\
5 \text { years but less than } 10 \text { years } \ldots \\
10 \text { years and over } \ldots \ldots \ldots \ldots \ldots \ldots \ldots \ldots\end{array}$ & $\begin{array}{l}26.1 \\
16.0 \\
31.9 \\
15.0 \\
11.0\end{array}$ & $\begin{array}{l}25.8 \\
17.4 \\
30.8 \\
15.6 \\
10.4\end{array}$ & $\begin{array}{r}31.4 \\
18.3 \\
32.2 \\
11.7 \\
6.4\end{array}$ & $\begin{array}{r}34.8 \\
17.6 \\
30.0 \\
11.0 \\
6.6\end{array}$ & $\begin{array}{l}18.9 \\
13.1 \\
34.6 \\
18.1 \\
15.3\end{array}$ \\
\hline \multicolumn{6}{|l|}{ Share tenants : } \\
\hline 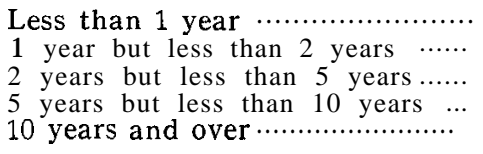 & $\begin{array}{r}37.3 \\
17.8 \\
28.4 \\
10.4 \\
6.1\end{array}$ & $\begin{array}{r}28.6 \\
18.1 \\
30.3 \\
14.2 \\
8.8\end{array}$ & $\begin{array}{r}34.7 \\
18.8 \\
31.2 \\
10.3 \\
5.0\end{array}$ & $\begin{array}{r}44.6 \\
18.2 \\
27.5 \\
3.9\end{array}$ & $\begin{array}{r}36.2 \\
16.5 \\
30.1 \\
10.4 \\
6.8\end{array}$ \\
\hline \multicolumn{6}{|l|}{ Average years on the same farm : } \\
\hline $\begin{array}{l}\text { All tenants } \\
\text { Cash tenants } \ldots \ldots \ldots \ldots \ldots \ldots \ldots \ldots \ldots \ldots \ldots \ldots \\
\text { Share tenants } \ldots \ldots \ldots \ldots \ldots \ldots \ldots \ldots \ldots \ldots \ldots\end{array}$ & $\begin{array}{l}3.0 \\
3.8 \\
2.6\end{array}$ & $\begin{array}{l}3.4 \\
3.7 \\
3.3\end{array}$ & $\begin{array}{l}2.6 \\
2.8 \\
2.5\end{array}$ & $\begin{array}{l}2.2 \\
2.8 \\
2.0\end{array}$ & $\begin{array}{l}3.6 \\
4.8 \\
2.7\end{array}$ \\
\hline
\end{tabular}

* Based on 1910 Census.

Source: W. J. Spillman and E. A. Goldenweiser, Farm tenantry in the U. S., Yearbook of the Department of Agriculture, 1916, p. 24. 
long-term leases were not necessary, because whose farms were likely to be sold in the course of a few years to those who would cultivate the land as owner-farmers. But the actual length of leases seemed to be too short beyond the extent which may be rationalized by the above explanation. Based on the Census in 1910, tenants having been on the same farm of less than 1 year were 33.4 percent of all tenants, 26.1 percent of cash tenants and 37.3 percent of share tenants in the whole U. S. If it was measured by average years on the same farm, only 3.0 years of all tenants, 3.8 years of cash tenants and 2.6 years of share tenants. Furthermore, if we concerned about the geographical difference, the rate of White tenants of all tenants, cash tenants, and share tenants having been on the same farm of less than 1 year was much higher in the South than those in the North or in the West. And the average years on the same farm was shorter than those in other regions (Table 12).

Under such a short term of cultivation on rented farms, neither landlord nor tenant especially the latter may be sufficiently interested in making necessary improvements on the farm. The landlord may not be confident that the succeeding series of tenants will maintain the improvements once they made. So that, tenants plant their lands of soil-depleting crops, more erosion is occurring on rented farms than on owner-operated farms because of the psychological effect on the renting family of the instability and insecurity of tenure, and becasue of the lack of vital interest in the property which was but temporarily in their care. There is a famous saying of "He that favocs may sit, he that improves must flit (Taylor, 1925). It will express well the common belief among the tenant farmers who cultivate their lands on short lease. The shortterm lease in the U. S. was one of the subjects which had to be readjusted in the direction of continuation to a reasonable extent.

2. The landlord-tenant relationship

Henry C. Taylor stated in 1925 that the first point to be considered by landlords in making a leasing contract is the character of the tenant and every point talked over by the owner and tenant should be written clearly and simply, and all the necessary items should be contained in the written agreement. The items illustrated by Taylor were (1) use of property, (2) disposition of products, (3) use of manure made on the farms, (4) purchase of feed and fertilizers, (5) destruction of noxious weeds, (6) new buildings and fences, (7) repairs on fences and buildings, (8) duration of lease, (9) amount of rent to be paid, (10) time of paying rent, (11) guaranteed that the rent shall be paid, (12) enforcing the agreements, (13) notice to terminate lease, and so on.

The above indication suggests that the oral contract instead of written contract was common and it did not usually contain every important item as above stated in the U. S. at that time.

Moreover, the followings were being discussed as the points which sould be paid enough attention. We may regard them as one of the problems concerning the relation between landlords and tenants.

(a) In an ideal system of landownership, the state shall have land commission which shall concern itself with land problems. The commission shall enforce the law and provisions which regulate tenancy and landlord-tenant 
relationship. It shall also try to make reports based on careful knowledge and enable us to proceed constructively, step by step, in the elaboration of sound land policies.

(b) In an ideal system of landownership there will be an endeavor to create in the landowner a feeling that landownership carries with it a social mission, and landowners must try to help those who are their tenants.

(c) It is probable also that under proper conditions the organizations of landlords and of tenants may be beneficial. Those organizations can be made to operate in a spirit of mutual fairness, cooperating with public extension agencies in the efforts to attain a better understanding of local renting arrangement. They may help to focus public opinions on the problem of improving the landlord-tenant relations, particularily in the interest of better systems of farming.

\section{The type of lease}

Whether a landlord should let his land on crop-share lease or on cash lease depends on the amount of time he can spend for the supervision of the farm and on the amount of money and ability possessed by the tenant. The landlord who lets his land on crop-share must give much attention to the management of the farm, but he who lets his land for cash lease needs to pay little attention to the farm beyond securing of a good tenant under proper agreement. Share tenancy usually yields larger returns to the landlord than cash tenancy because he renders more service, takes more risk and often furnishes more of the capital. Share tenancy was more common than cash tenancy in the U. S. before 1935 because it was preferred by many tenant farmers. It was because of the risk due to crop failure or annual fluctuations in yields and prices of crops which was less in share tenancy than in case tenancy, many of the young tenants did not possess sufficient money to pay for stocks, machinery and equipment, and for all other expenditures needed to operate the farm. On the other hand, the landlord preferred also crop-share leasing because it was more profitable to him.

Landlords who live too far from their lands or are too busy to give the supervision needed for making share tenancy successful usually prefer to let their farms for a cash rent, but it is claimed by many landlords that the tenants devote much greater care to their farming under the cash system. This is the greatest source of trouble in adjusting the relations between landlords and tenants. With all the difficulties which may beset this-system, cash tenancy is preferable to share tenancy whenever the management of the farm is to be left almost entirely to the tenant. And wherever agriculture is extensive and the use of the commercial fertilizers is unknown, the letting of land for cash is a fairly successful method. The experience of England shows that the compensation for unexhausted improvements is more successful than long leases as a means of solving the problem of good farming by cash tenants. This will be stated in the next section.

In the dairy regions, the stock-share method of renting had been used, but during that time a large number of questions with regard to the duties and privileges of landlords and tenants had arisen. Those questions may be solved 
by including the ownership of the partnership property, description of property furnished by the tenant, description of labor to be employed upon the farm, feed, colts raised by the tenant, poultry, the use of agricultural machines, management of the farm, sharing the proceeds, division of partnership property at the termination of lease in the leasing contract (Taylor, 1925).

4. The improvments of the method of compensations

Compensations for the unexhausted portion of the improvements should be much more significant under the circumstances where short-term leasing is the most typical form of tenancy as it was in the U. S. prior to 1935. However, the customary practice and the formal legislation concerning this problem was much more behind in the U. S. than that in England. The experience in England as for the improvements in the practice of compensations, the method of evaluation for the remaining value of the improvements, and the legislation relevant to this subject seemed to be very important for learning to the U. S.

\section{(1) The improvement of the evaluation of compensations}

The amount of compensation due to the outgoing of tenant may be determined by a mutual agreement between the landlord and the tenant, by a prearranged schedule contained in the contract, or by arbitration. The objective evaluation of the unexhausted value of the improvements should be the basis of the mutual agreement.

The valuation of certain unexhausted improvements may be difficult at first, but it will become relatively easy when better evaluation techniques have been developed, when research in soil fertility has progressed to the place where the residual effect of different fertilizers and measures has been determined, and when depreciation schedules on buildings and fences have been more accurately established. The amount of compensation for disturbance may be the actual loss or damage experienced, a specified sum, on the stated percentage of the annual rental.

Compensation could probably be more effectively applied to cash leases than to share leases. Under the cash lease the tenant usually maintains more control over the operation of the farm and receives the entire benefit of the improvements made on the farm at least during the time he operates it. Compensations may also be more easily solved when the term of lease is longer than in the reverse case.

Therefore, improvements of the method of compensation in the U. S. should be developed combining the improvements of the evaluation of compensations with the improvements on the type of tenancy and the duration of lease.

\section{(2) The experience of legislation relating to compensations in England}

Describing briefly the development of legislation concerning with compensations in England for our own convenience, the tenant right meant security for invested capital and compensation of unexhausted improvements in Lincolnshire system of England for instance. It was the right which was acquired by tenant farmers through struggles with landlords. But in some regions the system was not giving good results, because it was promoting an extensive system of fraud and falsehood among the farmers.

In 1850, a bill was introduced in parliament which aimed at the embodiment 
of this system into the law entitiled "A Bill for the Improvements of the Relation between Landlord and Tenant in England and Wales", but did not pass, and then, it finally passed in 1875. In 1883, "The Agricultural Holdings Act" was enacted. It contained a clause making it illegal for the landlord to contract out of the conditions of the law, and the tenant may obtain compensations. Additions were made in 1908 as the followings :

(1) Relating to damages to crop from the game, but no right to take compensation if the damage is under 1 shilling per acre.

(2) Compensation for unreasonable disturbance.

Legislation for compensations had been developed in England or in Wales through the course as above stated on the one hand, and on the other hand the average period of occupancy of the farm by tenants in England was over four times longer than that in the U. S. As a result, the farm property was relatively well maintained and in many cases actually improved in England.

To the contrary, it was finally in 1936 when the President's Special Committee on Farm Tenancy recommended in the U. S. the legislation concerning with compensation. The recommendation required

(1) that the landlord shall compensate the tenant for specified unexhausted improvements which he does not remove at the time of quitting the holding provided that for certain types of improvements the prior consent of the landlord is obtained.

(2) that the tenant shall compensate the landlord for any deterioration or damage due to factors over which the tenant has control, and the landlord shall be enpowered to prevent continuance of serious wastage.

(3) that after the first year payment shall be made for inconvenience or less substained by the other party by reason of termination of the lease without due cause.

(4) that if manure is exceeded, exclude from compensations. Wastes, injures the soil or destroys the improvements, the landlord may claim for payment, but the tenant can remove permanent improvement unless the landlord buys it.

\section{CONCLUSION}

Arthor Young, the well-known author of the book of "Travel in France", said that landownership is the magic which made gold of sands. But R. T. Ely and C. J. Galpin wrote in the paper entitled "Tenancy in an Ideal System of Landownership" as follows :

"...Tenancy is also a good thing when it represents a rung in the agricultural ladder and means a step upward in the winning of a competence. Sometimes and frequently a man begins as an agricultural laborer, saves money enough to become a tenant, then through tenancy acquires enough to purchase a farm, gives back a mortgage and gradually pays for this mortgage.. ."

Ownership is not only one absolute measure of land tenure but tenancy is also a useful measure and a good thing, if a better relation between landlords 
and tenants has been kept and tenancy represents economizing of capital in expanding the size of farm business and an ascending step in becoming a farmer for a young man who has no land and enough money to buy a farm under the condition of high land value.

The experience of the development of tenancy in the U. S. before 1935 was very suggestive for us from many respects. It was apparent that the year to year lease had many defects. However, the American experience seemed to suggest that the duration of lease would become shorter in the places where landlords are mostly consisted of small-sized residental owners who can keep close contact with their tenants and who undertake a part of the responsibility of farming as it was the case in the U. S., and in those places defective effects of short term lease would be largely reduced if a good landlord-and-tenant relationship is kept. So, it can be said that the improvement in the compensation for unexhausted improvements, the readjustment of short term lease to a moderate length of duration, and the good relationship and congenial contract between landlord and tenants are all important in expecting a sound future development of tenancy in Japan or Taiwan.

It was also interesting that the stock-share lease was the type of tenancy which was born and developed in livestock farming areas in the U. S. If a farm which has been organized and established as a specialized livestock farm is rented out, the stock-share lease or some other similar type of leasing must be adopted, and the improvements in the evaluation technique of livestock and other kinds of farm assets would be very important in order to develop such type of leasing.

In any case, it is certain that the development of tenancy on a reasonable, sound basis is neccesary for a structural change of small-sized, traditional agriculture in the countries like Japan or Taiwan.

\section{ACKNOWLEDGEMENTS}

The authors wish to thank Dr. Goki Kawanami, Professor, Dr. Toshio Sato, Assistant and Mr. Izumi Iwamoto, Research Student of the Seminar of Farm Management, Faculty of Agriculture, Kyushu University for their constructive comments and assistances.

\section{REFERENCES}

Black, J. D. and R. H. Allen 1937 The growth of farm tenancy in the U. S.. The Quarterly Journal of Economics, 51: 393-425

Ely, R. T. and C. J. Galpin 1919 Tenancy in an ideal system of landownership system. American Economic Review, 9: 180-212

Ely, R. T. and G. S. Wehrwein 1940 Land Economics. The Macmillan Company

Gray, L. C. 1920 Helping landless farmers to own farms. In "Yearbook of the U. S. Department of Agriculture", No. 844

Gray, L. C. 1924 Introduction to Agricultural Economics. The Macmillan Company

Galpin, C. J. and E. F. Moag 1919 Farm tenancy: an analysis of the occupancy of 500 farms. Agriculture Experiment Station of the University of Wisconsin, Research Bulletin 
No. 44

Gray, L. C. C. L. Stewart, H. A. Turner, J. T. Sanders and W. J. Spillman 1923 Farm ownership and tenancy. In "Yearbook of the U. S. Department of Agriculture", No. 897

Harris, M. D. 1937 The suggested adjustment in the farm tenancy system. Journal of Farm Economics, 19 : 892-900

Holmes, C. L. 1923 Relation of types of tenancy to types of farming in Iowa. Agricultural Experiment Station, Iowa College of Agriculture and Mechanic Arts, Bulletin No. 214

Spillman, W. J. 1919 The agriculture ladder. American Economics Review, 9: 170-179

Spillman, W. J. and E. A. Goldenweiser 1916 Farm tenantry in the U. S. In "Yearbook of the Department of Agriculture", No. 715

Stauber, B. R. 1937 Observations on land value trends. Journal of Farm Economics, 19 : 148-160

Taylor, H. C. 1925 Outlines of Agricultural Economics. The Macmillan Company 